\title{
Assessment of Patient Satisfaction with Pharmaceutical Community Services in R. Macedonia
}

\author{
Zoran Sterjev*, Bogdan Vlaco, Aleksandra Kapedanovska Nestorovska, Zorica \\ Naumoska, Aleksandra Grozdanova, Ljubica Suturkova
}

National Drug Information Centre, Faculty for Pharmacy, University St. Cyril and Methodius - Skopje, R.Macedonia

Received: May 2011; Accepted: June 2011

\begin{abstract}
Measuring and analyzing patients' satisfaction with pharmacist's consultation is a relatively new development which is enforced by the new demands of society. High number of variables, such as their state of health, socio-demographic variables (age, sex, and cultural level), characteristics of their healthcare provider (affective care, quantity of information, technical expertise, etc), or waiting time are related to patients' satisfaction. At present, in R.Macedonia, there are 834 community pharmacies, which accounts for pharmacy vs. population ratio of 1:2500. The pharmacies are situated in 8 different regions (the Vardar region, Pelagonia, North-East, South-West, Polog, East and South East). The present cross-sectional descriptive study based on interview data was carried out in order to ascertain patients' satisfaction from their experience with the cumulative quality of pharmaceutical services. A total of 651 patients of both sexes $(59,3 \%$ male and $39,1 \%$ female) were included in the study. The results from our analysis showed the influence of different factors in the process of choosing pharmacy: distance, medicines price, well-stocked with medicines, professional advice by the employees in the pharmacy, hygiene in pharmacies, the privacy they offer, waiting time, possibility for private conversation with professionals.
\end{abstract}

Key words: pharmacy, patients' satisfaction, pharmaceutical community service, R.Macedonia

\section{Introduction}

Optimization of the patient's health-related to the quality of life and achieving positive clinical outcomes, within realistic economic expenditures is one of the primary goals of the pharmaceutical services. Community pharmacy practice is inspired by the changing philosophy of practice where the patient is in focus, rather than the physical drug products or the business aspects of pharmacy. Recently, the role of the pharmacists is changing from traditional drug dispensing to a more active and participative role in risk assessment, risk management, and other medicationrelated consultation activities (Traveso et al., 2007).

The patients evaluation of the care provided has become a prominent method of assessing the quality of health care services (Rubin et al., 1993). It mainly refers to the pa-

\footnotetext{
"zost@ff.ukim.edu.mk
}

tient's satisfaction with the health care services and providers (Sitizia and Wood, 1997). Measuring and analyzing patient's satisfaction with consultations provided by pharmacists is a relatively new strategy which is enforced by the new demands of society.

High number of variables, such as their state of health, socio-demographic variables (age, sex, and cultural level), characteristics of their healthcare provider (effective care, quantity of information, technical expertise, etc), or waiting time are related to patients' satisfaction (Marquez-Peiro and Perez-Peiro, 2008). At present, in R. Macedonia, there are 834 community pharmacies, which accounts for pharmacy vs. population ratio of 1:2500. All community pharmacies are licensed and regulated by the Ministry of Health through the Drug Bureau. Privatization of pharmacies was allowed since 2004. Most of the pharmacies are concentrated in the urban areas. Numerous rural settlements have no/limited access to a pharmacy. Almost $30 \%$ of the total number of pharmacies is located in the capital city of our 
country. The other pharmacies are located at the 7 statistical regions of pharmacies in the country (Pelagonia, the Vardar region, North- East, South-West, Polog, East and South East) according to the official pharmacy network in R.Macedonia.

The Drug Bureau announced officially that in order to be licensed, a pharmacy should consist of at least one licensed graduated pharmacist and one licensed pharmaceutical technician (Official Gazette of the Republic of Macedonia 106/2007).

The present study was carried out in order to ascertain the levels of patients satisfaction with pharmaceutical service taking into consideration the social, traditional and professional aspects of the pharmaceutical health care system in R.Macedonia.

\section{Methods}

Two month's cross-sectional descriptive study based on interview data was carried out in order to establish patients' satisfaction with the cumulative quality of pharmaceutical service based on their experience. The specially developed and designed questionnaire for measuring patients' satisfaction with pharmaceutical service was used. The multiple-choice questionnaire was prepared in accordance with "14 rules for writing multiple-choice question" (Brigham Young University). One of the questions concerning the hygiene in pharmacies, well-stocked with medicines, time of waiting and possibility of clients to have private conversation with professionals was prepared in conformity with Likert Scaling. The questionnaire consisted of 12 questions divided in the following sections: demographic profile of the responders; aspects of pharmaceutical practice; important factors for choosing a community pharmacy, contentment for receiving both verbal and written medication information in community pharmacies and aspects/issues concerning national drug policy. The eligible, randomisely selected patients, on voluntary and confi- dential basis, were interviewed in front of /inside community pharmacies in different regions of R.Macedonia (Skopje, Pelagonia, the Vardar, North East, South-West, Polog, East and South-East region). Inclusion criteria for participation in the study were age (above 16), Macedonian citizenship and willingness of the subject to participate in the study. For the statistical analysis, Kruskal-Wallis test was used for testing the hypothesis that a number of unpaired samples originate from the same population. Group comparisons were made using Chi square test for qualitative variables. Statistical significance was assessed at $\mathrm{p} \leq 0.05$.

\section{Results and Discussion}

A total of 651 patients of both sexes $(59,3 \%$ male and $39,1 \%$ female) were included. The structure of respondents regarding the territorial distribution by different regions (Skopje, Pelagonia, the Vardar, North East, SouthWest, Polog, East and South-East region), marked by numbers from 1 to 8 , and population coverage by the pharmacies where data collection took place are show in Table 1. The statistical analysis doesn't include the South-Eastern region due to the low frequency of occurrence of only $1,7 \%$ in the total structure.

The results from our analysis showed the influence of different factors in the process of choosing a pharmacy: the distance is mainly the most important element for the patients from the North-Eastern region - 51,7\%. The price of medicines, as a rule, determines the selection of a pharmacy with patients living in the territory of the Vardar and North- Eastern region (23,2\% and 24,2\% respectively). Respondents from the South- Western region mainly select the pharmacy which is well stocked - 39,5\%. Professional advice by the employees in the pharmacy is of higher priority for the respondents from the region of Pelagonia - 22,2\%, Eastern region - 24,2\% and South-East region $-28,6 \%$.The results obtained are in line with our expectation that various factors influence the process of choosing pharmacies in different re-

Table 1. Structure of respondents regarding the territorial distribution by different regions

\begin{tabular}{|c|c|c|c|c|c|c|c|}
\hline & Regions & Count & Cumulative & Percent & Cumulative & $\begin{array}{l}\text { Number of phar- } \\
\text { macies in the re- } \\
\text { gion }\end{array}$ & $\begin{array}{l}\text { Population cov- } \\
\text { er by pharmacy }\end{array}$ \\
\hline 1. & Skopje & 351 & 351 & 53,75191 & 53,7519 & 247 & 617500 \\
\hline 2. & Pelagonia & 72 & 423 & 11,02603 & 64,7779 & 127 & 317500 \\
\hline 3. & Vardar & 56 & 479 & 8,57580 & 73,3538 & 57 & 142500 \\
\hline 4. & North-East & 29 & 508 & 4,44104 & 77,7948 & 59 & 147500 \\
\hline 5. & South-West & 38 & 546 & 5,81930 & 83,6141 & 92 & 230000 \\
\hline 6. & Polog & 36 & 582 & 5,51302 & 89,1271 & 106 & 265000 \\
\hline 7. & East & 58 & 640 & 8,88208 & 98,0092 & 77 & 192500 \\
\hline \multirow[t]{2}{*}{8.} & South-East & 11 & 651 & 1,68453 & 99,6937 & 78 & 195000 \\
\hline & Missing & 2 & 653 & 0,30628 & 100,0000 & & \\
\hline
\end{tabular}


Table 2. Differences in the answers to the question "Do you take your medicines from the same pharmacy?" among the respondents from different regions

Kruskal-Wallis test: $\mathrm{H}(6, \mathrm{~N}=640)=15,85 \mathrm{p}=, 01$

\begin{tabular}{lcccccccccc}
\hline Doyou take your medicines from the same pharmacy? & 1 & 2 & 3 & 4 & 5 & 6 & 7 & 8 & row \\
& $\mathrm{N}$ & 49 & 15 & 11 & 10 & 13 & 11 & 10 & 3 & 122 \\
Always & $\%$ & 13,8 & 20,8 & 19,6 & 34,5 & 34,3 & 30,5 & 17,3 & 42,9 & \\
& $\mathrm{~N}$ & 165 & 39 & 21 & 13 & 11 & 15 & 27 & 1 & 292 \\
From the same pharmacy if the medicines I & $\%$ & 47,1 & 54,2 & 37,5 & 44,8 & 28,9 & 41,7 & 46,5 & 14,3 & \\
need are available & $\mathrm{N}$ & 137 & 18 & 24 & 6 & 14 & 10 & 21 & 3 & 233 \\
I don't have "my pharmacy" & $\%$ & 39,1 & 25,0 & 42,9 & 20,7 & 36,8 & 27,8 & 36,2 & 42,8 & \\
Column & & 351 & 72 & 56 & 29 & 38 & 36 & 58 & 7 & 647 \\
\hline
\end{tabular}

1-Skopje region, 2- Pelagonyan, 3-Vardar, 4- Nort-East, 5- South-West, 6- Polog, 7- Easterly, 8- South-East

gions. This process is probably due to differences in ethnicity, education level, social, financial and demographic factors.

We also tested out the combinations of these four offered responses which refer to the potential priorities when choosing a pharmacy, and the statistical differences in priorities when selecting a pharmacy for patients from different regions were confirmed as highly significant, i.e. important $(\mathrm{p}<0.001)$. We evaluated the differences in the answers of the question "Do you always take your medicines from the same pharmacy?". The highest percentage of patients coming from the region of Skopje $(47,1 \%)$, Pelagonia $(54,2 \%)$, from North-East region $(44,8 \%)$, from Polog region $(41,7 \%)$, and from the Eastern region (46,5\%) answered that they take their necessary medicines from the same pharmacy, if they are available. The tested difference in the answers to the question among the respondents from different regions is statistically significant and it is the result of the considerable difference between Skopje and Pelagonia region, Skopje and NorthEastern region, between the Vardar and North-Eastern region as well as between the Polog and the Eastern region. (Table 2). The introduction of fixed prices for prescribing medicines a few years ago, can be the reason which influences the patients' perception of the quality of the pharmaceutical service as a main factor for choosing the pharmacy.

Results which refer to the hygiene-related grade marks given by the respondents coming from different regions show the lowest average grade mark of 4,4 for the pharmacies from the Polog and the Eastern region, while the pharmacies in the North-East region were given the highest average mark. Half of the respondents coming from all the regions gave the maximum mark of 5 related to the hygiene in pharmacies. A statistically significant difference $(\mathrm{p}>0.05)$ was not registered. The patients' perception and satisfaction with the waiting time differ significantly among the regions. The data obtained are presented in Table 3.

The answers of respondents from different regions differ significantly in their grading of the possibility for private conversation with a pharmacist without being overheard by someone else in the pharmacy. This parameter average marks are low for all the regions and they range from 2,1 for pharmacies on the territory of North-East region, 2,4 for the Skopje region to 3,5 for pharmacies in the

Table 3. Respondents from different regions about the waiting time in pharmacies

\begin{tabular}{ccccc}
\hline \hline 54 Kruskal-Wallis test: $\mathrm{H}(6, \mathrm{~N}=631)=72,80704 \mathrm{p}=, 0000$ & \\
\hline Regions & Valid N & Mean & Std.Dev. & Median \\
Skopje & 345 & 3,4 & 1,1 & 3,0 \\
Pelagonia & 71 & 4,1 & 1,0 & 4,0 \\
Vardar & 56 & 3,9 & 0,8 & 3,0 \\
Nort-East & 28 & 3,5 & 0,8 & 4,0 \\
South-West & 38 & 4,6 & 0,7 & 5,0 \\
Polog & 36 & 3,8 & 0,9 & 4,0 \\
East & 57 & 3,8 & 1,1 & 4,0 \\
South-East & 12 & 3,2 & 1,1 & 3,0 \\
\hline
\end{tabular}

Макед. фарм. билт., 56 (1, 2) 23 - 28 (2010) 
Table 4. The possibility of having private conversation with a professional staff member in the pharmacy according to different regions.

\begin{tabular}{lcccc}
\hline \hline 55 Kruskal-Wallis test: $\mathrm{H}(6, \mathrm{~N}=626)=48,25485 \mathrm{p}=, 0000$ & & & \\
\hline Regiones & Valid $\mathrm{N}$ & Mean & Std.Dev. & Median \\
Skopje & 340 & 2,4 & 1,4 & 2,0 \\
Pelagonia & 70 & 3,4 & 1,5 & 4,0 \\
Vardar & 56 & 2,9 & 1,5 & 2,0 \\
Nort-East & 29 & 2,1 & 0,9 & 2,0 \\
South-West & 38 & 3,5 & 1,6 & 4,0 \\
Polog & 35 & 2,5 & 1,1 & 3,0 \\
East & 58 & 3,2 & 1,6 & 3,0 \\
South-East & 12 & 2,8 & 1,7 & 3,0 \\
\hline
\end{tabular}

Table 5. Evaluation of the patients' communication with professionals in pharmacies

\begin{tabular}{lcccccccccc}
\hline \hline Kruskal-Wallis test: $\mathrm{H}(6, \mathrm{~N}=640)=64,83320$ & $\mathrm{p}=, 0000$ \\
\hline In the pharmacy, patients have a contact & & 1 & 2 & 3 & 4 & 5 & 6 & 7 & 8 & Row \\
with .... & $\mathrm{N}$ & 73 & 43 & 31 & 7 & 22 & 13 & 18 & 3 & 210 \\
Pharmacist & $\%$ & 20,8 & 59,7 & 55,4 & 24,2 & 57,9 & 36,1 & 31,1 & 42,9 & \\
& $\mathrm{~N}$ & 61 & 10 & 9 & 6 & 0 & 3 & 16 & 1 & 106 \\
Pharmaceutical technician & $\%$ & 17,4 & 13,9 & 16,1 & 20,7 & 0 & 8,3 & 27,6 & 14,3 & \\
& $\mathrm{~N}$ & 217 & 19 & 16 & 16 & 16 & 20 & 24 & 3 & 331 \\
Undefined & $\%$ & 61,8 & 26,4 & 28,5 & 55,1 & 42,1 & 55,6 & 41,3 & 42,8 & \\
Column & & 351 & 72 & 56 & 29 & 38 & 36 & 58 & 7 & 647 \\
\hline
\end{tabular}

South-West region. (Table.4). Unfortunately, there is a lack of space, time and habit for private consultation in almost all pharmacies in our country. The reason for this might be the number of licensed pharmacists, suitable facilities and patients' expectations for this type of services.

While most of the respondents that contacted the pharmacist were from the region of Pelagonia - 43(59,7\%) and the Vardar region $-31(55,4 \%)$, most of the respondents from the Eastern region contacted the pharmaceutical technician $-16(27,6 \%)$. It is also interesting to note that as many as $217(61,8 \%)$ respondents from the region of Skopje were unable to answer this question since they did not know the educational level of the provider of pharmaceutical services.. The difference in the distribution of answers given by the respondents from different regions is statistically highly significant $(\mathrm{p}<0.0001)$. (Table 5)

Patients cannot distinguish between the pahramceutical care provided by licensed pharmacists and pharmaceutical technicians. We believe that the quality of pharmaceutical services given to the patients is the major reason which is responsible for this evaluated situation. The following results are in accordance with our assumptions.

The grade mark given by patients from various regions regarding the employees in the pharmacy, with regard to the information they are supplied with, differs significantly. Most frequently, the staff in the pharmacy gives the necessary information to $61,9 \%$ of patients in the region of Pelagonia, $75,9 \%$ in the North-East region, $71,1 \%$ in the SouthWest and $71,4 \%$ in the Eastern region, without even being asked. The staff gives the necessary information upon patients' request according to $53,6 \%$ of the respondents in the Vardar region and 53,4\% in the Eastern region. The lowest number of respondents answering that they were not given the necessary information is registered in the Eastern region $-1,8 \%$. None of the respondents from the North-East and South-West region answered that the pharmacy staff was unable to give them the necessary information. The respondents from various regions differ significantly regarding the confidence they have in the pharmacist or pharmaceutical technician $(\mathrm{p}<0.001)$. The patients from the South-West region have considerably higher confidence in the professional staff in the pharmacy compared to those coming from Skopje, Vardar, Polog and Eastern regions. $14,2 \%$ of the patients from Skopje, 10,7\% from Vardar region, 8,3\% of the patients from the Polog region have no confidence in the pharmacy staff. All medicines prescribed by a physician were found in the pharmacy by $59,1 \%$ of the respondents in the region of Skopje, $70,8 \%$ in the Pelagonia region, 55,3\% 
in the Varda regionr, $79,3 \%$ in the North-East region, $89,5 \%$ in the South-West region, and 66,7\% in the Polog and Eastern regions. No respondents from the North-East, SouthWest, Polog and Eastern regions answered that they didn't find any of the prescribed medicines. The difference tested among the respondents from various regions with regard to the question of whether they could find all the medicines, part of the medicines or none of the medicines, is statistically highly significant $(p<0,001)$. The patients from the South-West region were able to find all the required medicine in the pharmacy in comparison with those from the region of Skopje, Pelagonia, Vardar, Polog and Eastern regions. The respondents from the North-East region find all the required medicines significantly more frequently than the ones from the region of Vardar. The patients are satisfied with the well stocked pharmacies on the well established pharmaceutical market in our country.

\section{Conclusion}

The present cross-sectional descriptive study is the first evaluation of the patients' satisfaction with pharmaceutical community services in R.Macedonia.The results obtained are preliminary and improvements are needed to identify the specific reasons for satisfaction/dissatisfaction with pharmaceutical services. Future research should be focused on developing a new instrument for measuring different levels of services provided by pharmacists.

\section{References}

Larson, L.N., Roverse, J.P., MacKeigan, L.D, 2002. Patient satisfaction With Pharmaceutical Care: Update of a Validated Instrument. J. Am. Pharm. Assoc. 42, 44-50.

Ministry of health, Macedonian government, 2007. Law on medical products and medical devices. Official Gazette of the Republic of Macedonia 106.

Marquez-Peiro, J.F., Perez-Peiro, C., 2008. Evaluation of Patient satisfaction in Outpatient Pharmacy. Farm. Hosp. 32 (2), 7176.

Rubin, H.R., Gandek, B., Rogers, W.H., Kosinski, M., Mc Horney, C.A., Ware, J.E.Jr., 1993. Patients ratings of outpatient visits in different practice settings: results from the Medical Outcomes Study. JAMA. 270, 835-840.

Sitizia, J., Wood, N., 1997. Patient satisfaction: a review of issues and concepts. Soc.Sci.Med. 45, 1829-1843.

Traveso, M.L., Salamano, M., Botta, C., Colautti, M., Palchik, V., Perez, B., 2007. Questions to asses patient satisfaction with pharmaceutical care in Spanish language. Int. J. Quality in Health Care. 19 (4), 217-224.

\title{
Резиме
}

\section{Определување на задоволството на пациентите од јавниот фармацевтски сервис во Р. Македонија}

\author{
Зоран Стерјев*, Богдан Влачо, Александра Капедановска Несторовска, Зорица \\ Наумоска, Александра Грозданова, Љубица Шутуркова
}

Национален Фармакоинформативен Центар. Универзитет „Св. Кирил и Методиј““ Скопје, Р.Македонија

Клучни зборови: аптека, задоволство на пациентот, фармацевтски сервис, Р. Македонија

Евалуацијата на стекнатото задоволство на пациентите од добиената фармацевтска грижа претставува релативно нов потфат предизвикан од современите потреби на општеството. Стекнатото задоволството на пациентите е условено од голем број на фактори како што се: нивната здраствена состојба, социо-демографките фактори (години, пол и културолошко ниво), карактеристиките на здравствени работници (потполна грижа, содржина и квантум на информации, техничка подготвеност итн.) или времето на чекање. Денес, во Р. Македонија има 834 јавни аптеки, со вкупна популациска распределба 1:2500 жители. Аптеките се распределени во 7 различни региони (Пелагониски, Вардарски, Североисточен, Југозападен, Полошки, Источен и Југоисточен). Спроведената студија претставува вкрстена студија, која се темели на податоци добиени од спроведени интервјуа со 651 корисник на фармацевтски услуги (59,3\% од машки и $39,1 \%$ од женски пол). Основната цел на испитувањето беше да се одреди задоволството на пациентите од добиената фармацевтска грижа и да се оцени квалитетот на истата. Резултатите од спроведената анализа упатуваат на влијание на различни фактори при процесот на избор на аптеката: оддалеченоста, цената на чинење на лековите, снабденоста со лековите, професионалните совети добиени од вработените во аптеката, хигиената во аптеката, овозможената приватноста во аптеките, времето на чекање, како и можноста за дискретен разговор со здравствените професионалци. 